\title{
EVALUATION OF METHODS FOR DETERMINING ABNORMALITIES IN CARDIOVASCULAR SYSTEM BY PULSE SIGNAL UNDER PSYCHO-EMOTIONAL STRESS IN DENTAL PRACTICE
}

\section{Yevhenia Yavorska; Oksana Strembitska; Mykhailo Strembitskyi; Lilia Hvostivska}

\author{
Ternopil Ivan Puluj National Technical University, Ternopil, Ukraine
}

\begin{abstract}
Summary. The purpose of this paper is to compare the existing methods of pulse signal analysis in order to select the best methods for detecting psycho-emotional stress in dental practice. The carried out analysis showed that analytical methods are the most promising for the creation of new and improvement of existing diagnostic equipment, as they contain clear algorithms and have high reproducibility of calculation results.

Key words: analysis, cardiovascular system, method, psycho-emotional stress, pulse signal.
\end{abstract}

Statement of the problem, its importance. Assessment of the patient's psychoemotional state during the dentist's visit is an urgent problem, as psycho-emotional stress results in physiological changes, being one of the reasons for limiting blood flow and persistent vasospasm due to loss of their ability to dilate. Changes in cardiovascular system activity (including short-term) are the factors of reducing the reliability of cardiovascular system, increasing its sensitivity to various destabilizing effects. Excessive stress response is a risk factor for the development and progress of hypertensive crisis, myocardial infarction, cardiovascular accident and death from sudden cardiac arrest [1].

In the context of modern medical care in Ukraine, in the number of applications and the number of specialists in this field, dentistry at present is inferior only to general therapy and ranks second in medical field [2]. Diagnosis of the oral cavity and dental interventions are referred to the mass types of medical care. Statistical studies of the Ministry of Health Care of Ukraine [3] indicate that out of the total number of respondents of 10,000 people, $41 \%$ of respondents underwent preventive examinations by dentist (estimate 2019). The number of consulting the doctor has clear distribution by age groups (Fig. 1) - the number of visits to the doctor for preventive examination in the group of respondents aged 45 and above is reducing, and one of this phenomenon factors is an attempt to avoid stress associated with visiting the dentist, because in $50.9 \%$ of cases the need of carrying out dental manipulations is established.

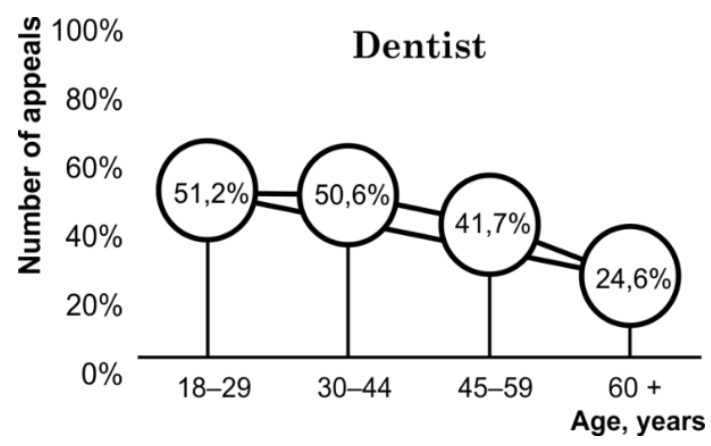

Figure 1. Percentage of respondents who underwent dental medical examination for prophylactic purposes within 12 months 
Analysis of available investigations and publications. The occurrence of emergencies at the dentist is quite common predictable phenomenon, caused by specific factors of outpatient dental visit. These factors are grouped into the following categories:

- mass type of medical care, so there is not always enough time for comprehensive patient examination (the patients often change the dentist, which is the reason for the lack of medical history or data fragmentary);

- concomitant somatic pathologies;

- $\quad$ psycho-emotional stress resulting in body's stress response;

- $\quad$ negative emotional memories associated with visiting the dentist's office in the past;

- $\quad$ toxic effect of anesthetic drugs [4].

According to the data provided by Popova K. A. [5], the distribution of emergencies is shown in Fig. 2. It is evident from the sample results that in $61 \%$ of cases, emergencies are associated with the cardiovascular system disorders.

The task of emergencies distribution by the reason of their occurrence is a difficult task, because in most cases it is caused by the combination of several factors. The selection of the dominant factor requires a systematic approach to the analysis of possible reasons. One of the ways to determine the change in cardiovascular system activity caused by psycho-emotional stress at the dentist's office, is the evaluation of the changes in qualitative and quantitative indicators of heart rate.

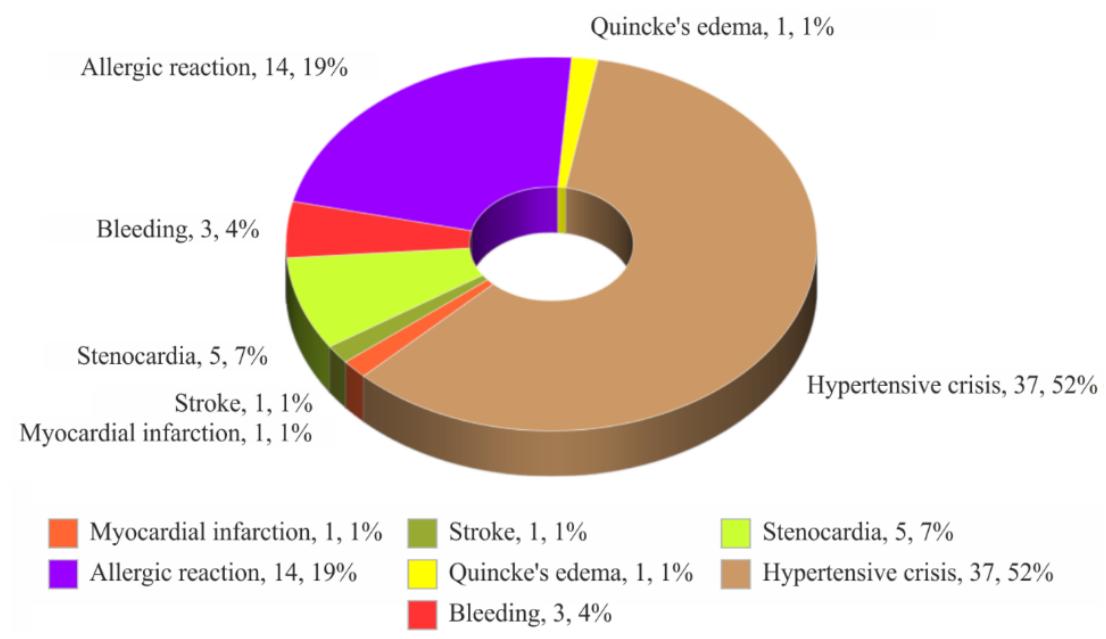

Figure 2. Distribution of emergencies in dentistry (total number of patients with emergencies 73-20 men, 53 women)

Objective of the paper is to evaluation the methods for determining abnormalities in the cardiovascular system by pulse signal in order to predict the occurrence of emergencies in dental practice.

Statement of the problem. Since stress is non-specific reaction of the body in response to a very strong action (stimulus) outside, which exceeds the norm, as well as the corresponding reaction of the nervous system [6], then in his works $\mathrm{R}$. Lazarus put forward the concept according to which stress can be divided into physiological, the occurrence of which is associated with a real physiological stimulus and mental (emotional) one, which is associated with the assessment of a person's evaluation of the future situation as threatening, difficult. This stress division is quite conditional, as physiological stress includes emotional component, and there is no physiological changes in psycho-emotional stress. On the basis of existing physiological changes - particularly changes in cardiovascular system - it is possible to diagnose some psychological disorders, such as depression [7]. Psychoemotional stress caused by the expectation of discomfort and possible pain while visiting the dentist, also results in 
physiological changes in the body activity. Determination of psychoemotional state of the patient by means of pulse signal involves analysis of the existing methods and selection of those ones that provide repeatability and unambiguous interpretation of the data, without subjective component and based on clear algorithms for results analysis and evaluation.

Results of the investigation. Methods of pulse signal analysis can be divided into three main groups - graphical method, analytical method and qualitative method [8].

The graphical method is based on the analysis of characteristic signal points along the time axis and amplitude indicators of the signal using of signal normalization by characteristic points relatively to the axis. Waves of I, II and III order are distinguished in the pulse signal. Waves of II and III order are referred to slow waves, and waves of I order are referred to fast waves and are correlated with the pulse. They reflect the blood movement along the vessels at the measured point during systole and diastole. Figure 3 shows I order waves reflecting the volume pulse (I), II order waves coinciding with respiratory waves (II) and III order waves corresponding to several respiratory waves (III).

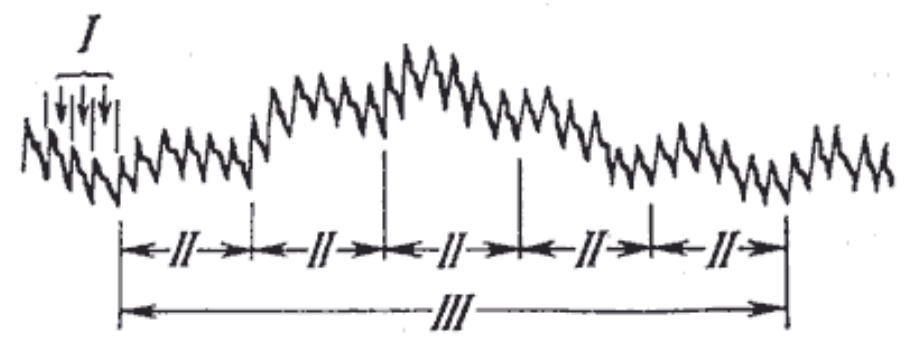

Figure 3. The structure of the pulse signal: I - first-order waves, II - second-order waves, III - third-order waves

The graphical method of pulse signal analysis is based on the analysis of the main structural units of pulse signal - anacrotic $\left(A_{1}\right)$ and dichroic $\left(A_{2}\right)$ half-waves. The schematic representation of the pulse wave is given in Fig. 4 (a). The pulse signal parameters that have diagnostic value are divided into amplitude and time ones, which is due to the wave structure. During systole, the first peak of pulse wave is formed, which corresponds to the anacrotic pulse wave period (Fig. 4, a). The maximum value of the pulse wave amplitude corresponds to the stroke volume during systole. The second peak of the pulse wave is formed by the pulse wave reflection from the walls of aorta and large main vessels and partially corresponds to the diastolic period of the cardiac cycle. It carries information about vascular tone. The pulse wave frequency and duration depends on the heart characteristics, and the size and shape of the peaks - on the vascular system state. Figure 4 (b) shows the characteristic points of the pulse wave.

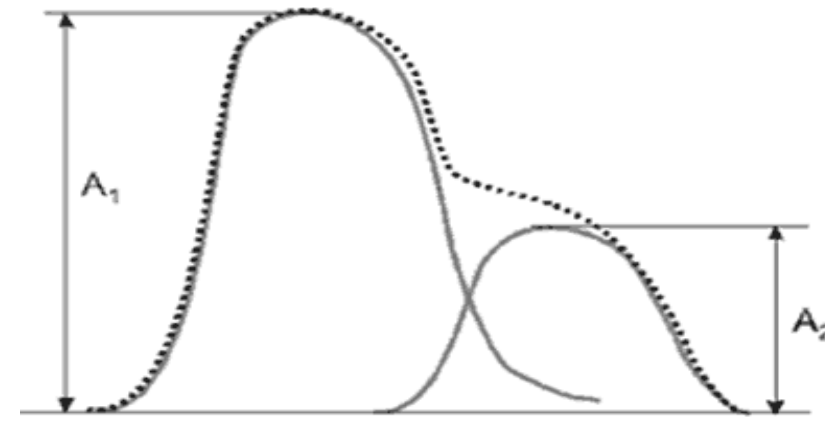

a)

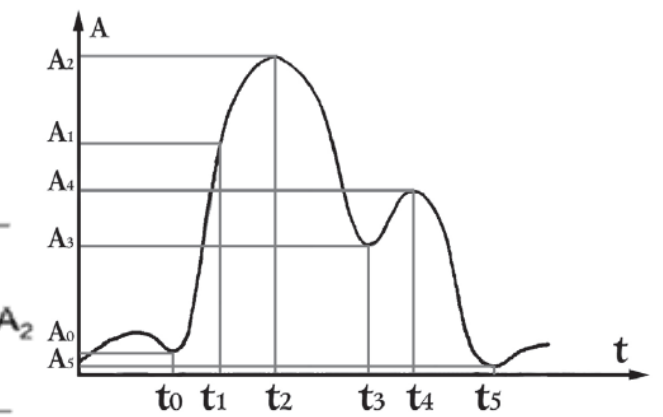

b)

Figure 4. Schematic representation of the pulse wave phases (a), schematic reproduction of the pulse wave with characteristic points (b) 
The pulse signal parameters for evaluation the cardiovascular system activity are divided into four groups:

1. The amplitude characteristics of the pulse wave are studied along the vertical axis (Fig. 4, b). These parameters are relative, but their study in dynamics provides valuable information about the strength of the vascular response. In this group of parameters the amplitudes of anacrotic $\left(A A X=\mathrm{A}_{2}-\mathrm{A}_{0}\right)$ and dichroic wave $\left(A Д X=\mathrm{A}_{4}-\mathrm{A}_{5}\right)$, dichroic wave index $\left(\right.$ ІД $\left.X=\left(\mathrm{A}_{3}-\mathrm{A}_{5}\right) /\left(\mathrm{A}_{2}-\mathrm{A}_{0}\right) \times 100\right)$ are studied. The latter indicator is absolute.

2. The temporal characteristics of the pulse wave are studied along the horizontal axis containing information cardiac cycle duration of systole and diastole. These parameters can be compared with other methods of collecting information about the state of the cardiovascular system, such as electrocardiography (ECG), because they are absolute. In this group we study the anacrotic phase duration of the pulse wave $\left(t_{A}=t_{2}-t_{0}\right)$, the duration of the dichroic phase of the pulse wave $\left(t_{\mathrm{A}}=t_{5}-t_{3}\right)$, the duration of the expulsion phase $\left(t_{\Phi \mathrm{B}}=\right.$ $\left.t_{3}-t_{2}\right)$, the duration of the pulse wave $\left(t_{\Pi \mathrm{X}}=t_{5}-t_{0}\right)$, rising wave index, filling time $\left(t_{\mathrm{YH}}=t_{2}-\right.$ $t_{0}$ ), duration of the systolic phase of the cardiac cycle, duration of the diastolic phase of the cardiac cycle, pulse wave reflection time, heart rate $[8,9]$.

3. Parameters that can be calculated using the data of the previous groups - dichroic wave index characterizing such indicators as: position of the dichroic wave peak relatively to the anacrotic one, the ratio of anacrotic and dichroic phases duration. The calculation of these parameters makes it possible to assess the influence of external physical factors on the state of the cardiovascular system both during short and long periods of time of stimulus action.

4. Statistical ones, determining the variability of amplitude-time parameters for pulse waves during long period of time (minutes).

The graphical method has a number of disadvantages - the shape of the signal and its characteristic points deviate significantly from the norm for a number of cardiovascular system diseases, which exclude the possibility to use standard algorithms for data interpretation. Therefore, analytical and qualitative methods of signal processing are also used for signal analysis.

Analytical method. The analytical method is based on the periodicity of the pulse signal in the time domain. This makes it possible to use Fourier signal for analysis - based on the harmonic component of the pulse signal, the most characteristic emissions and depressions are distinguished.

Fourier transformation for such signals is represented by formula (1):

$$
a_{0}+\sum_{k=1}^{\infty}\left(a_{k} \cos k x+b_{k} \sin k x\right)
$$

Coefficients $a_{0}, a_{k}$ and $b_{k}$ are obtained using formulas (2)-(4):

$$
\begin{gathered}
a_{0}=\frac{1}{2 \pi} \int_{0}^{2 \pi} f(x) d x, \\
a_{k}=\frac{1}{\pi} \int_{0}^{2 \pi} f(x) \cos (k x) d x,
\end{gathered}
$$




$$
b_{k}=\frac{1}{\pi} \int_{0}^{2 \pi} f(x) \sin (k x) d x
$$

Analysis of the signal in the frequency domain makes it possible to determine by means of signal spectrum the changes that are undistinguished in the time domain. This in turn improves the diagnostic value of the selected signal.

Discrete Fourier transformation, short time and fast Fourier transform are used to convert the signal from the time domain to the frequency domain. The essence of the discrete Fourier transformation is that the signal is evaluated at points that are typical for the signal similar to all other signals.

Short time Fourier transform is used for non-periodic signals. In short time Fourier transform, the input signal $f(t)$ is divided into parts and each part is analyzed separately by its frequency content. The effect of the short time is to localize the signal in time.

The signal deviation is usually accompanied by values outlier, as the deviations in most cases have relatively larger parameters and values. Other fluctuations of values pass smoothly.

Signal analysis in two-dimensional space of time and frequency makes it possible to present continuous wavelet transformation. Unlike Fourier transformation, the wavelet transformation makes it possible to investigate the change in time of instantaneous amplitudes and rhythms frequencies, which is especially important for the investigation of nonstationary processes in the dynamics of living systems, where frequency and time are considered as independent variables. Wavelet transformation enables to expand the tool base of information technologies for data processing [10].

In paper [11] it is proposed to calculate the contribution of individual functions using formulae of Euclidean distance and absolute distance for the determination the pulse signal parameters. The pulse signal is dynamic, so for its analysis additional tools for nonlinear time series analysis are used. These series make it possible to evaluate various features of the main signal dynamics - spectral analysis, nonlinear deterministic prediction, calculation of Poincare cross section, Weiland test and surrogate data method. These methods are aimed at checking the random components of the signal, such as dependence on the initial conditions, predictability and determinacy [12]. It is also important to carry out analysis not only by selecting one or more parameters having diagnostic value, but also to carry out complex analysis, one of which options is multifractal analysis using the phases of the signal obtained by Fourier transformation [13].

Since the pulse signal is the signal of biological origin, it can be represented as a piecewise stationary random process [14] and analyzed using the methods of spectral correlation analysis [15].

The use of analytical methods requires a large number of hardware and software resources, due to the complexity of the software implementation of these functions with subsequent statistical analysis.

Qualitative method. Quantitative pulse parameters do not provide comprehensive information about the nature of pulse signal in cases where the signal has no characteristic amplitude and time marks. While analyzing such signal, graphical and quantitative methods become less informative.

The example of qualitative analysis is the determination of certain cardiovascular system diseases by means of characteristic pulse signal contour (Fig. 5) [16]. 


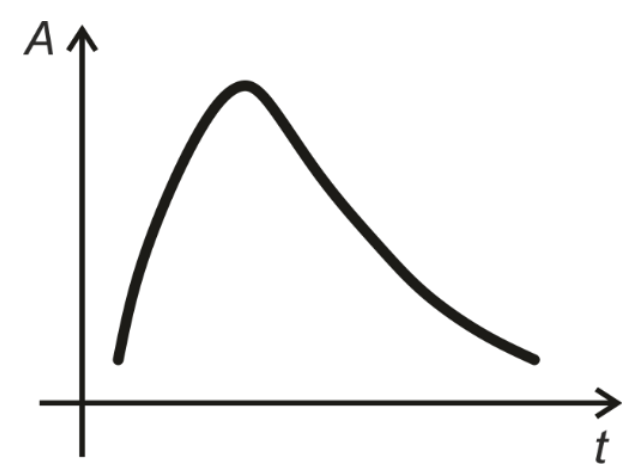

a)

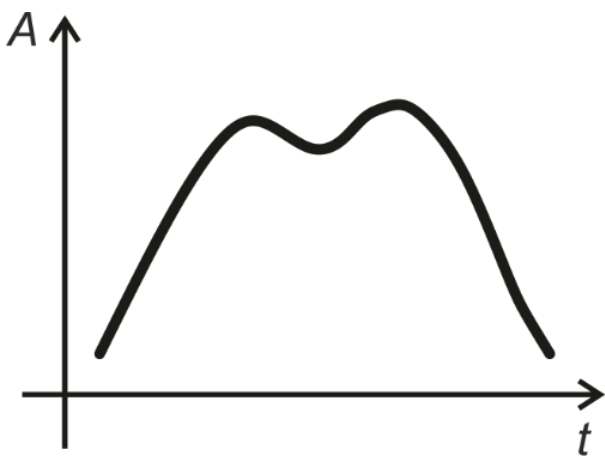

c)

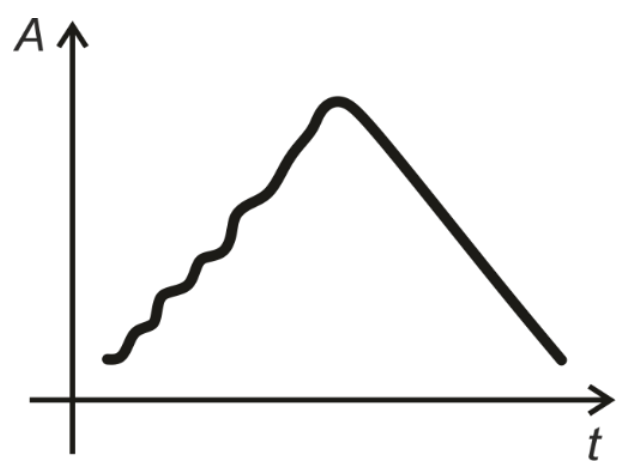

b)

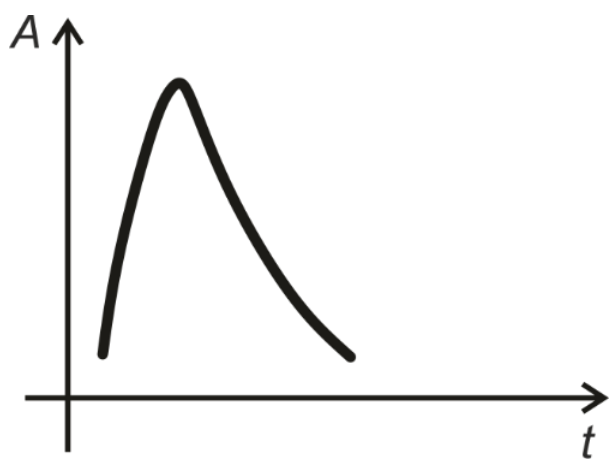

d)

Figure 5. The pulse wave contour at: a) norm; b) pulse with slow rise and reduced amplitude - aortic stenosis; c) bispheric pulse - the combination of severe aortic insufficiency with moderate stenosis of the aortic orifice; d) jumping pulse - aortic or mitral insufficiency

Qualitative analysis is used for rapid diagnosis of a number of diseases (vegetativevascular dystonia, diabetes mellitus, atherosclerosis, etc.), but it requires highly qualified medical staff to make decisions causing difficulties in diagnosis automation.

Comparative characteristics of pulse signal analysis methods are shown in table 1.

Table 1

Comparison of pulse signal analysis methods

\begin{tabular}{|c|c|c|c|c|c|c|}
\hline \multirow{2}{*}{$\begin{array}{c}\text { Pulse wave } \\
\text { analysis } \\
\text { method }\end{array}$} & $\begin{array}{c}\text { Signal } \\
\text { visualization }\end{array}$ & $\begin{array}{c}\text { Automation of } \\
\text { signal analysis }\end{array}$ & $\begin{array}{c}\text { Possibility of } \\
\text { concomitant } \\
\text { parameters } \\
\text { calculation }\end{array}$ & Accuracy & $\begin{array}{c}\text { Hardware and } \\
\text { software resources }\end{array}$ & $\begin{array}{c}\text { Results } \\
\text { reproducibility }\end{array}$ \\
\hline $\begin{array}{c}\text { Graphic } \\
\text { method }\end{array}$ & $\begin{array}{c}\text { Screen - } \\
\text { waveform and } \\
\text { parameters }\end{array}$ & High & Yes & High & $\begin{array}{c}\text { Insignificant }- \\
\text { simple } \\
\text { calculations }\end{array}$ & $\begin{array}{c}\text { Yes - for individual } \\
\text { patient, within the } \\
\text { average value }- \text { for } \\
\text { a group of patients }\end{array}$ \\
\hline $\begin{array}{c}\text { Analytical } \\
\text { method }\end{array}$ & $\begin{array}{c}\text { Screen - analysis } \\
\text { results }\end{array}$ & High & Yes & High & $\begin{array}{c}\text { Significant }- \\
\text { complex } \\
\text { calculations }\end{array}$ & Yow \\
\hline $\begin{array}{c}\text { Qualitative } \\
\text { method } \\
\text { about the } \\
\text { deviation of the } \\
\text { waveform from } \\
\text { the norm - } \\
\text { norm/deviation }\end{array}$ & $\begin{array}{c}\text { Low (with the } \\
\text { involvement of } \\
\text { a specialist) }\end{array}$ & No & Low & $\begin{array}{c}\text { Partially - within } \\
\text { the reproduction of } \\
\text { the waveform }\end{array}$ \\
\hline
\end{tabular}


Conclusions. It is evident from the carried out analysis of the methods for determining abnormalities in cardiovascular system by pulse signal, that in order to create new and to improve existing diagnostic equipment the most promising are the analytical methods, as they contain clear algorithms and have high reproducibility of calculation results, and this provides their software implementation. However, conducting the adequate analysis of changes in the cardiovascular system associated with psycho-emotional stress at the dentist requires modeling of biophysical processes and methods of their analysis using mathematical description of processes and the use of synthesized on their basis pulse signal models for the evaluation of the obtained pulse signal analysis algorithms. The obtained data show that the application of analytical method is perspective for obtaining additional parameters that have diagnostic value while determining changes in cardiovascular system activity associated with psycho-emotional stress at the dentist.

\section{References}

1. Dem'yanenko S. A. Psie'mocional'noe napryazhenie $v$ rozvitii gipertenzivnyx reakcij na stomatologicheskom prieme. Vyatskij medicinskij vestnik. 2014. No. 3-4. P. 53-56. [In Russian].

2. Vakhnenko O. M. Analiz resursnoho zabezpechennya stomatolohichnoyi sluzhby v Ukrayini. Sovremennaya stomatolohyya. 2011. No. 3. P. 172-176. [In Ukrainian].

3. Ukl. Bars'ka Yu., eds. Indeks zdorov"ya. Ukrayiny-2019: Rezul'taty zahal'nonatsional'no doslidzhennya. 2020. 103 p. URL: https://www.researchgate.net/publication/339800140_Indeks_zdorov'a_Ukraina_2019_Rezultati_zagalnonacionalnogo_doslidzenna. [In Ukrainian].

4. Nevidkladni stany u stomatolohiyi, shcho zahrozhuyut' zhyttyu. URL: https://navistom.com/blog/ nevidkladni-stani-v-stomatologiyi-shcho-zagrozhuyut-zhittyu-12766.html. [In Ukrainian]

5. Rasprostronennost' neotlozhnyx sostoyanij $\mathrm{v}$ ambulatornoj stomatologicheskoj praktike g. Volgograda. URL: https://files.scienceforum.ru/pdf/2012/1115.pdf. [In Russian].

6. Mintsera O. P Suchasni metody i zasoby dlya vyznachennya i diahnostuvannya emotsiynoho stresu: monohrafiya. Vinnytsya: VNTU, 2010. 228 p. [In Ukrainian].

7. Tuan D. Phama, Truong Cong Thang, Mayumi Oyama-Higacd, Masahide Sugiyamae (2013) Mentaldisorder detection using chaos and nonlinear dynamical analysis of photoplethysmographic signals. Chaos, Solitons \& Fractals. Vol. 51. P. 64-74. DOI: https://doi.org/10.1016/j.chaos.2013.03.010

8. Malinovskij E. L. Uchebno-metodicheskoe posobie po ispol'zovaniyu pal'cevoj fotopletizmografii. URL: http://www.tokranmed.ru/metod/fpg_clinik_1.htm.5. [In Russian].

9. Markov S. M., Skoryukova S. M. Strukturno-zv"yaznostna model' fotopletyzmohrafichnoho syhnalu. Optyko-elektronni informatsiyno-enerhetychni tekhnolohiyi. 2014. No. 2. P. 41-47. [In Ukrainian].

10. Yue-Der Lin, Ya-Hsueh Chien, Yi-Sheng Chen (2017) Wavelet-based embedded algorithm for respiratory rate estimation from PPG signal. Biomedical Signal Processingand Control. Vol. 36. P. 138145. DOI: https://doi.org/10.1016/j.bspc.2017.03.009

11. A. Reşit Kavsaoğlu, Kemal Polat, M. Recep Bozkurt (2014) A novel feature ranking algorithm for biometric recognition with PPG signals. Computersin Biology and Medicine. Vol. 49. P. 1-14. DOI: https://doi.org/10.1016/j.compbiomed.2014.03.005

12. Nina Sviridova, Kenshi Sakaib (2015) Human photoplethysmogram: new insight into chaotic characteristics. Chaos, Solitons \& Fractals. Vol. 77. P. 53-63. DOI: https://doi.org/10.1016/j.chaos.2015.05.005

13. P. Ch. Ivanov, L. A. Nunes Amaral, A. L. Goldberger, S. Havlin, M. G. Rosenblum, Z. R. Struzik, H. E. Stanley (1999) Multifractality in human heartbeat dynamics. Nature. Vol. 399. P. 461-465. DOI: https://doi.org/10.1038/20924

14. Dozorska O. (2018) The mathematical model of electroencephalographic and electromyographic signals for the task of human communicative function restoration. Scientific Journal of TNTU (Tern.). Vol. 92. No. 4. P. 126-132. DOI: https://doi.org/10.33108/visnyk_tntu2018.04.126

15. Nykytyuk V., Dozorskyi V., Dozorska O. (2018) Detection of biomedical signals disruption using a sliding window. Scientific Journal of TNTU (Tern.). Vol. 91. No. 3. P. 125-133. DOI: https://doi.org/10.33108/visnyk_tntu2018.03.125

16. Issledovanie sosudistoj sistemy. URL: https://en.ppt-online.org/354139. [In Russian].

\section{Список використаної літератури}

1. Демьяненко С. А. Псиэмоциональное напряжение в розвитии гипертензивных реакций на стоматологическом приеме. Вятский медицинский вестник. 2014. № 3-4. С. 53-56.

2. Вахненко О. М. Аналіз ресурсного забезпечення стоматологічної служби в Україні. Современная стоматология. 2011. № 3. С. 172-176. 
3. Індекс здоров'я. України-2019: Результати загальнонаціонально дослідження / укл. Барська Ю. та ін. Київ, 2020. 103 с. URL: https://www.researchgate.net/publication/339800140_Indeks_zdorov'a_Ukraina__2019_Rezultati_zagalnonacionalnogo_doslidzenna.

4. Невідкладні стани у стоматології, що загрожують життю. URL: https://navistom.com/blog/ nevidkladni-stani-v-stomatologiyi-shcho-zagrozhuyut-zhittyu-12766.html.

5. Распростроненность неотложных состояний в амбулаторной стоматологической практике г. Волгограда. URL:https://files.scienceforum.ru/pdf/2012/1115.pdf.

6. Сучасні методи і засоби для визначення і діагностування емоційного стресу: монографія / за заг. ред. О. П. Мінцера. Вінниця: ВНТУ, 2010. 228 с.

7. Tuan D. Phama, Truong Cong Thang, Mayumi Oyama-Higacd, Masahide Sugiyamae Mental-disorder detection using chaos and nonlinear dynamic alanalysis of photoplethysmographic signals. Chaos, Solitons \& Fractals. 2013. Vol. 51. P. 64-74. DOI: https://doi.org/10.1016/j.chaos.2013.03.010

8. Малиновский Е. Л. Учебно-методическое пособие по использованию пальцевой фотоплетизмографии. URL: http://www.tokranmed.ru/metod/fpg_clinik_1.htm.5.

9. Марков С. М., Скорюкова Я. Г. Структурно-зв'язностна модель фотоплетизмографічного сигналу. Оптико-електронні інформаційно-енергетичні технології. 2014. № 2. С. 41-47.

10. Yue-Der Lin, Ya-Hsueh Chien, Yi-Sheng Yi-Sheng Chen Wavelet-based embedded algorithm for respiratory rate estimation from PPG signal. Biomedical Signal Processing and Control. 2017. Vol. 36. P. 138-145. DOI: https://doi.org/10.1016/j.bspc.2017.03.009

11. A. Reşit Kavsaoğlu, Kemal Polat, M. Recep Bozkurt A novel feature ranking algorithm for biometric recognition with PPG signals. Computersin Biologyand Medicine. 2014. Vol. 49. P. 1-14. DOI: https://doi.org/10.1016/j.compbiomed.2014.03.005

12. Nina Sviridova, Kenshi Sakaib Human photoplethysmogram: new insight into chaotic characteristics. Chaos, Solitons \& Fractals. 2015. Vol. 77. P. 53-63. DOI: https://doi.org/10.1016/j.chaos.2015.05.005

13. Ivanov P. Ch., Nunes Amaral L. A., Goldberger A. L., Havlin S., Rosenblum M. G., Struzik Z. R., Stanley H. E. Multifractality in human heartbeat dynamics. Nature. 1999. Vol. 399. P. 461-465. DOI: https://doi.org/10.1038/20924

14. Dozorska O. The mathematical model of electroencephalographic and electromyographic signals for the task of human communicative function restoration. Scientific Journal of TNTU. 2018. Vol. 92. No. 4. P. 126-132. DOI: https://doi.org/10.33108/visnyk_tntu2018.04.126

15. Nykytyuk V., Dozorskyi V., Dozorska O. Detection of biomedical lsignals disruption using as liding window. Scientific Journal of TNTU. 2018. Vol. 91. No. 3. P. $125-133$. DOI: https://doi.org/10.33108/visnyk_tntu2018.03.125

16. Исследование сосудистой системы. URL: https://en.ppt-online.org/354139.

\title{
УДК 612.16
}

\section{ОЦІНЮВАННЯ МЕТОДІВ ВИЗНАЧЕННЯ ВІДХИЛЕНЬ У ДІЯЛЬНОСТІ СЕРЦЕВО-СУДИННОЇ СИСТЕМИ ЗА ПУЛЬСОВИМ СИГНАЛОМ ПРИ ПСИХОЕМОЦЙНОМУ СТРЕСІ У СТОМАТОЛОГІЧНІЙ ПРАКТИЦІ}

\section{Свгенія Яворська; Оксана Стрембіцька; Михайло Стрембіцький; Лілія Хвостівська}

\author{
Тернопільський національний технічний університет імені Івана Пулюя, \\ Тернопіль, Україна
}

\footnotetext{
Резюме. Проведення діагностики ротової порожнини та надання стоматологічної допомоги належить до масових видів медичної допомоги. Прийом у лікаря-стоматолога часто супроводжується психоемоційним напруженням, яке зумовлене очікуванням дискомфорту та можливого болю під час стоматологічних маніпуляцій, щзо призводить до фізіологічних змін у діяльності організму, зокрема зміни у діяльності сериево-судинної системи. Зміни у діяльності серцево-судинної системи (у тому числі й короткотривалі) є фактором зниження надійності функціонування серцево-судинної системи підвищення їі чутливості до різних дестабілізуючих впливів. Актуальним завданням є визначення психоемочійного стану пацієнта за пульсовим сигналом, що передбачає вибір методів аналізу сигналу. Метою роботи $\epsilon$
} 
Evaluation of methods for determining abnormalities in cardiovascular system by pulse signal under psychoemotional stress in dental practice

оиінювання методів визначення відхилень у діяльності сериево-судинної системи за пульсовим сигналом для прогнозування виникнення невідкладних станів у стоматологічній практииі. Проведено порівняння методів аналізу пульсового сигналу та проведено оцінювання можливості їх використання для визначення змін у діяльності сериево-судинної системи при психоемоційному стресі у стоматологічній практиці. Із проведеного аналізу очевидно, що для створення нової та удосконалення існуючої діагностичної апаратури найперспективныциими є аналітичні методи, оскільки вони містять чіткі алгоритми й мають високу відтворюваність результатів обчислення, а це дає можливість їх програмної реалізації. Однак проведення адекватного аналізу змін у діяльності сериево-судинної системи, пов'язаного з психоемоційним стресом на прийомі у лікаря-стоматолога, потребує моделювання біофізичних процесів та методів їх аналізу з використанням математичного опису процесів та використання синтезованих на їх основі моделей пульсового сигналу для оцінювання отриманих алгоритмів аналізу пульсового сигналу. Отримані дані свідчать, що застосування аналітичного методу має перспективи отримання додаткових параметрів, які несуть діагностичну цінність при визначенні змін у діяльності сериево-судинної системи, які пов'язані з психоемоційним стресом на прийомі у лікаря-стоматолога.

Ключові слова: аналіз, метод, психоемоиійне напруження, пульсова хвиля, сериево-судинна система. 